\title{
GENDER EQUALITY INDEX FOR COUNTRY REGIONS
}

\author{
AVOLIO Beatrice ${ }^{1}$, DEL CARPIO Luis ${ }^{2}$
}

\author{
${ }^{1}$ CENTRUM Católica Graduate Business School, Lima, (PERU) \\ ${ }^{2}$ CENTRUM Católica Graduate Business School, Lima, (PERU) \\ Email: bavolio@pucp.pe
}

\begin{abstract}
This study introduces a gender equality index for country regions (GEIR) that provides a comprehensive approach for quantitatively measuring the gender equality and social progress at a sub-national level, as well as the ability of subnational governments to translate the economic growth into social progress. The main contributions of this index are the distribution of resources between women and men and the inclusion of regional differences.

The GEIR includes four pillars, twelve factors and a set of indicators. This GEIR was applied to 26 regions of Peru and the results show a low level of achievement in both the development of men and women and a significant gender gap.
\end{abstract}

Keywords: Social progress, gender, gender equality, regional progress

JEL: $J 16$

UDC: $305-055.1 / .2: 311 . a 316.64: 305-055.11 .2$

COBISS.SR-ID: 18171145

\section{Introduction}

Gender equality is a key element to achieve a peaceful, prosperous and sustainable development [1].Gender equality means that both women and men "have the same status and equal opportunities to fully enjoy their human rights and to contribute to the national, political, economic, social, and cultural development and, hence, benefit from the results" [2].

The right to equality and non-discrimination is included in the international system for human rights protection and in various international instruments. In spite of this, there are still troubling gender disparities in the world. According to the World Economic Forum, from 2006 to 2018, the gap in health, education, and political and economic opportunities between men and women only decreased by 3.6\%. Moreover, despite an increased number of women among technical workers, the gap in economic opportunity will take 202 years to close.

Similarly, although there has been great political progress worldwide, there is still low female political representation (women represent 24 percent of parliamentarians and 18 percent of the world's cabinet ministers). In addition, there is not a direct proportion between the number of highly educated women, skilled female workers, and women leaders [3].

The United Nations Population Fund [4]stated that gender equality will only be achieved when women and men coexist in an environment where the decision power is equally distributed in order to have the same opportunities, rights, and obligations that lead to economic independence, education and the achievement of personal goals. In this context, the Gender Equality Index for Country Regions (GEIR) is developed and it is composed of 4 pillars, 12 factors, and 32 indicators. It aims to expose the reality of men and women based on the analysis of different factors that influence the subnational areas. The index can be a useful tool for the development of public policies and a guide for strategic social investment. This 
paper introduces the methodology used for developing the GEIR and the results of its application in Peru.

\section{Literature Review}

Key international documents were analyzed to develop GEIR. For instance, the Platform for Action of the Fourth World Conference on Women in Beijing [5] which fostered women's empowerment, reaffirming the commitment to fully develop women's potential and specific aspects [6]. The "Millennium Development Goals" [7] and the "Sustainable Development Goals" set in 2015 by the United Nations also emphasized the achievement of gender equality and the empowerment of women and girls, the abolition of discrimination and violence against women, recognition of unpaid work, the participation of women in decision-making, ensure women's sexual and reproductive health, among others [1].

Gender equality can be defined as the equal duties, rights, responsibilities, and opportunities for men and women in the various aspects of life, recognizing the particularities of both without reducing them to sexual differentiation. It also involves building an environment with accessibility and fair use of resources that are essential for democratic societies and personal growth. Development in this category implies "removing the traditional culture, values, and gender roles that reproduce and maintain the subordination of women" [8]. The concept of gender equality recognizes that, historically, women have been discriminated against and it is necessary to close the gaps between women and men. Equal opportunities for women and men are essential for building political, social, and economic democratic societies [9].This requires several key reforms to achieve equal rights in economic resources, properties, land, and services and to create policies and laws that promote gender equality and the empowerment of women and girls, such as the abolition of discrimination and violence against women, the recognition of unpaid work, the promotion of participation of women in decision-making, and the assurance of women's sexual and reproductive health [1].

Table 1. Gender Equality Indices

\begin{tabular}{|l|l|l|l|l|}
\hline Index & Global Gender Gap Index & $\begin{array}{l}\text { Gender } \\
\text { Development } \\
\text { Index }\end{array}$ & $\begin{array}{l}\text { Gender Inequality } \\
\text { Index }\end{array}$ & $\begin{array}{l}\text { Social Progress } \\
\text { Index: }\end{array}$ \\
\hline Author & World Economic Forum & United Nations Development Programme & $\begin{array}{l}\text { Imperative Social } \\
\text { Progress }\end{array}$ \\
\hline $\begin{array}{l}\text { Name of the } \\
\text { report }\end{array}$ & $\begin{array}{l}\text { Global Gender Gap } \\
\text { Report }\end{array}$ & Human Development Report & $\begin{array}{l}\text { Social Progress } \\
\text { Index Report }\end{array}$ \\
\hline $\begin{array}{l}\text { Publication } \\
\text { frequency }\end{array}$ & Annual & Annual & Annual \\
\hline $\begin{array}{l}\text { Number of } \\
\text { countries } \\
\text { included in the } \\
\text { study }\end{array}$ & 149 (year 2018) & 189 (year 2018) & 146 (year 2018) \\
\hline & $\begin{array}{l}\text { Describes the } \\
\text { performance of the } \\
\text { countries regarding the } \\
\text { gap between women and } \\
\text { men in order to } \\
\text { understand if the } \\
\text { countries distribute } \\
\text { equally the resources and } \\
\text { opportunities, regardless } \\
\text { of the levels of national }\end{array}$ & $\begin{array}{l}\text { Measures the } \\
\text { Human } \\
\text { Obevelopment } \\
\text { men and women. for }\end{array}$ & $\begin{array}{l}\text { Measures gender } \\
\text { inequality without } \\
\text { taking into account } \\
\text { the variables related } \\
\text { to economic growth. }\end{array}$ & $\begin{array}{l}\text { Evaluates the } \\
\text { effectiveness with } \\
\text { which a country's } \\
\text { economic success } \\
\text { translates into } \\
\text { social progress. }\end{array}$ \\
\hline
\end{tabular}




\begin{tabular}{|c|c|c|c|c|}
\hline & general revenue. & & & \\
\hline Dimensions & $\begin{array}{ll}\text { - } & \text { Workforce } \\
\text { involvement and } \\
\text { opportunities } \\
\text { - } \quad \text { Educational } \\
\text { - } \text { attainment } \\
\text { - } \quad \text { Pealth and survival } \\
\text { Political } \\
\text { empowerment } \\
\end{array}$ & $\begin{array}{ll}\text { - } & \text { Long and } \\
& \text { healthy life } \\
\text { - } & \text { Knowledge } \\
\text { - } & \text { Standard of } \\
& \text { living }\end{array}$ & $\begin{array}{ll}\text { - } & \text { Health } \\
\text { - } & \text { Empowerment } \\
\text { - } & \text { Labor market }\end{array}$ & - Opportunity \\
\hline Components & $\begin{array}{l}\text { Workforce involvement } \\
\text { and opportunities } \\
\text { Educational attainment } \\
\text { Health and survival } \\
\text { Political empowerment }\end{array}$ & $\begin{array}{l}\text { Long and healthy } \\
\text { Life } \\
\text { Knowledge } \\
\text { Standard of living }\end{array}$ & $\begin{array}{l}\text { Health } \\
\text { Empowerment } \\
\text { Labor market }\end{array}$ & $\begin{array}{l}\text { Opportunity } \\
\text { A }\end{array}$ \\
\hline Methodology & $\begin{array}{l}\text { The data are converted } \\
\text { into proportions between } \\
\text { women and men and were } \\
\text { subsequently made equal } \\
\text { to a benchmark (1). This } \\
\text { means equal numbers for } \\
\text { men and women in all } \\
\text { indicators, except for the } \\
\text { two health indicators } \\
\text { because these have a } \\
\text { different approach. Then, } \\
\text { a weighted average is } \\
\text { calculated in each } \\
\text { dimension (the score in } \\
\text { each indicator and the } \\
\text { weights). The value of the } \\
\text { dimension ranges from } 0 \\
\text { to } 1 \text {, where } 0 \text { is perfect } \\
\text { inequality and } 1 \text { perfect } \\
\text { equality. }\end{array}$ & $\begin{array}{l}\text { The index is } \\
\text { calculated } \\
\text { separately for men } \\
\text { and women. The } \\
\text { same } \\
\text { methodology } \\
\text { included in the } \\
\text { HDI is used. Each } \\
\text { dimension has the } \\
\text { same weight. The } \\
\text { same points of } \\
\text { reference included } \\
\text { in the HDI are } \\
\text { used to transform } \\
\text { the dimensions on } \\
\text { a scale that ranged } \\
\text { from } 0 \text { and } 1\end{array}$ & $\begin{array}{l}\text { The index includes } \\
\text { three dimensions } \\
\text { different from those } \\
\text { included in the HDI, } \\
\text { and these cannot be } \\
\text { interpreted as a loss } \\
\text { in the HDI. The } \\
\text { index scores range } \\
\text { from } 0 \text { to } 1 . \text { The } \\
\text { higher the value, the } \\
\text { higher the levels of } \\
\text { inequality will be. }\end{array}$ & $\begin{array}{l}\text { The index } \\
\text { includes three } \\
\text { elements: } 3 \\
\text { dimensions, } 12 \\
\text { components, and } \\
53 \text { indicators. The } \\
\text { factor analysis } \\
\text { statistically } \\
\text { determined the } \\
\text { weights. The } \\
\text { scores ranged } \\
\text { from } 0 \text { to } 100 \text {, } \\
\text { where } 100 \text { is the } \\
\text { highest score and } \\
0 \text { the lowest score. }\end{array}$ \\
\hline
\end{tabular}

Source: Developed based on the World Economic Forum [3], the United Nations Development Program, and Porter \& Scott [10]

In the 1970s, researchers started looking for indicators that considered other aspects besides economic growth. For this reason, they developed social indicators that considered health, education, and social progress. In the 1980s, instruments for measuring gender and indicators separated by gender that show their respective realities were needed [11] because the awareness of the importance of equality between men and women increased, and it was recognized as a positive element for personal growth, economic and social development in all countries. Currently, there are four indices of interest for this study: (a) the Gender Development Index (GDI); (b) the Gender Inequality Index (GII); (c) the Global Gender Gap and; (d) the Social Progress Index (SPI). The GDI and GII were developed by The United Nations Development Program (UNDP), the SPI by the Social Progress Imperative, and the Global Gender Gap by the World Economic Forum (Table 1).

The UNDP pioneered the development of gender indices and presented the GDI in the Human Development Report in 1995. This index studied the inequality based on the same aspects considered by the Human Development Index (HDI), calculating the same values: health, knowledge, and standard of living for men and women separately. The higher the value, the lower the difference between men and women. This received criticisms due to the 
combination of relative and absolute achievements, i.e., even though a country obtained a good score with respect to gender equality, the overall score was poor due to low income [12].

By 2006, the World Economic Forum introduced a new index, the Global Gender Gap Report. The index quantifies and qualifies the distribution of resources and opportunities between men and women. It analyzes four dimensions: economic participation and opportunity, educational attainment, political empowerment, and health and survival. Each dimension is composed of a set of indicators. The number of indicators in this index is 14 and, in 2018, the Global Gender Gap Report included 149 countries [3].

In 2010 the UNDP overcame the criticisms to the previous index and presented the Gender Inequality Index (GII). The GII covers three dimensions: reproductive health, empowerment, and labor market. Unlike the GDI, this index does not depend on allegations, i.e., it does not use a method to add missing data and none of the indicators are directly related to a country's economic growth. The Human Development Report (where the GDI and GII are included) published in 2018 included 189 countrie (UNDP, 2018). Finally, SPI offers a different approach. It measures a society's ability to meet the basic needs, increase the quality of life, and create conditions and opportunities to reach the population's potential. The index combines three dimensions: basic human needs, the opportunity for progress, and well-being.

These are broken down into 12 components; one of them addresses the gender issue [13].

The data used for these indices were collected from international sources. The Global Gender Gap Index draws on information retrieved from the International Labour Organization (ILO), the United Nations Educational, Scientific and Cultural Organization (UNESCO), among others. In addition, GDI and GII relied on databases created by the World Health Organization (WHO), the United Nations Population Fund (UNFPA), and the World Bank, among others. Finally, the Social Progress Index, for the gender aspect, retrieved information from UNESCO.

\section{Constructing an Index}

For the Organization for Economic Cooperation and Development (OECD) and the Joint Research Center (JRC), developing indicators involves a solid theoretical framework, a structure of the subgroups of the phenomenon, and a list of the selection criteria for the underlying variables [14]. The theoretical framework should provide a clear definition of what is measured, the subcomponents, and the underlying indicators. In addition, multidimensional concepts can be divided into several subgroups and the connections should be described theoretically or empirically [14]. The selection criteria for underlying indicators can be similarly developed and should serve as a guide to determine whether or not a variable should be included. A composite indicator is the sum of its parts; therefore, the variables must be selected by identifying the characteristics related to relevance, soundness, timeliness, accessibility, among others. Finally, even though a proper theoretical framework can lead to a sound indicator, the data used to build it is subjectively selected. The quality and accuracy of composite indicators benefit greatly from improvements in data collection and availability [14].

The adequacy of an indicator lies on its ability to capture part of the information related to a real phenomenon [11]. In order to achieve this, the indicator should comply with several basic conditions (a) validity, i.e., to show the actual differences of the characteristics that are measured; (b) reliability, i.e., the differences are not chance results or random errors; (c) sensitivity, i.e., the results must show finite distinctions of what is measured, and must be precise enough to reflect changes; (d) understandable, i.e., results should be easily interpreted to provide coherent information; and (e) accessibility, i.e., to obtain information and make calculations in an agile way [11]. The GEIR is a social indicator because it is "a statistical 
measure related to the amount or magnitude of a set of parameters or attributes of a society" [15] Specifically, it measures men's and women's current access to resources in various dimensions in each region. Social indicators can be classified according to the measurement objective. These can be impact, effect, and compliance indicators [16]. The GEIR is an impact index because it measures the social progress of gender equality at the end of a period. Gender indicators use the gender approach in statistics. The various factors that influence men and women differently are considered [17]. For this reason, ECLAC noted that the gender approach in statistics is necessary because it shows different roles, activities, tasks, and responsibilities for both sexes [18]. The first step in the statistical construction of the index was the standardization of the data collected, as the information is measured differently in each indicator. This was done with the following formula:

$$
\frac{(X i-\bar{X})}{(\text { Standard deviation })}=\text { INDICATOR } R_{i}
$$

$X i$ : Score of the indicator i

$\bar{X}$ : Average of the indicator $\mathrm{i}$

The following step was testing the variables of interest using Cronbach's alpha (CA). This allows estimating the internal consistency of the factors within each pillar. The OECD suggests a minimum threshold of 0.70 as an acceptable measure of reliability [14]. When the model was validated after verifying the consistency and suitability of the indicators, the weights had to be calculated - based on the Principal Component Analysis (PCA) - in order to obtain the GEIR. Therefore, the resulting index is the weighted average of the value obtained in one region in each of the three dimensions. The GEIR applies to men and women independently, which creates a general ranking for each group. This technique allows the combination of indicators in a component that captures the maximum value in data variance and reduces any redundancy among the indicators [13], thus leaving only the most important variables with weights according to their significance. Next, the Min-Max method [14] was used, which converts each variable into a score from 0 to 100 . To achieve this, the best-case scenario and the worst-case scenario, the utopia, and dystopia respectively, were used to benchmark each region and allow an effective comparison. In addition, the score is easy to interpret by both policymakers and interested citizens, making the progress of women and men in each region readable at a glance. This method is represented as follows:

$$
\frac{(\text { INDICATORi }- \text { Worst case scenario })}{(\text { Best scenario }- \text { Worst case scenario })}
$$

With the information already normalized and with solid verifications of internal consistency and goodness of fit, the last step is the aggregation of information. The GEIR is aggregated as follows, with each pillar having equal relevance in the equation:

Pillar $_{p}$ : Every pillar in the index.

$$
\text { GEIR }=\frac{1}{4} * \sum_{d} \text { PILAR } p
$$

Each pillar includes factors that represent independent concepts related to the pillar, since they have equal significance for the GEIR, the weight is the same:

$$
\text { Pillar }_{p}=\frac{1}{3} * \sum_{f} \text { CFACTOR }_{f}
$$


Pillar $_{p}$ : Every pillar in the index.

CFACTOR $_{f}$ : Factor $\mathrm{f}$ within the pillar $\mathrm{p}$.

Similarly, the factor is the sum of ${ }_{i}$ weighted indicators determined by the principal component analysis:

$$
\text { FACTOR }_{f}=\sum_{i}\left(W_{i} * \text { INDICATOR }{ }_{i}\right)
$$

FACTOR $_{f}:$ Factor $\mathrm{f}$ within the pillar $\mathrm{p}$

INDICATOR $_{i}$ : Indicator $\mathrm{i}$ within the factor $\mathrm{f}$

$W_{i}$ : Weight of each indicator $\mathrm{i}$ within the factor $\mathrm{f}$.

After this, a second test to verify the goodness of fit, the Kaiser-Meyer-Olkin (KMO), was run. In general, this value should exceed the 0.5 threshold [19]. Therefore, all factors with a KMO value equal to or greater than 0.50 were selected.

\section{Gender Equality Index for Country Regions (GEIR)}

Based on the literature review, GEIR is composed of 4 pillars, 12 factors, and 32 indicators analyzed by sex in each of the country regions. These pillars are social progress, education, health, autonomy, and opportunity. Each pillar has three factors. The education pillar includes the following factors: (a) primary education, (b) secondary education, and (c) educational attainment. The health pillar: (a) access, (b) morbidity, and (c) basic care. The autonomy pillar: (a) economic autonomy, (b) physical autonomy, and (c) decision-making autonomy.

The opportunities pillar: (a) access to higher education, (b) employment, and (c) time use.

These variables were chosen due to their theoretical relevance in gender equality and social progress in the literature review, which will be explained for each pillar (Tables 1, 2, 3 and 4).

\section{Education}

The Education pillar includes factors that measure women's and men's educational development levels. It takes into account primary and secondary education, considering enrollment and attendance, and educational attainment, which covers the literacy level and years of completed studies.

The pillar education is included because the access to education and higher levels of schooling are the main accomplishments achieved by women. However, those achievements are not directly proportional to the economic equality and power of this population [18]. The UNESCO Institute for Statistics [20] estimated that, worldwide, two-thirds of illiterate adults are women and 16 million girls will never go to school. Educational shortcomings will limit women's access to information and opportunities [14]. Moreover, several studies showed the positive effects of the mother's education on their children and on the reduction of poverty factors [18]. Strengthening women's education is a collective benefit. A higher level of education is related to lower infant fertility, mortality rates, and better outcomes for their descendants [14].

Concerning the access to education, girls are the least favored in certain regions due to the level of poverty, violence, culture, among other reasons. There are also gender gaps in the academic performance at school, due to the household situation (which is related to the mother's lack of education in comparison with the father's), regardless of the school status (public or private). In addition, according to the student's ethnicity, these performance gaps can increase in regions [21]. These previous studies showed that the efforts should focus on reducing gender gaps because educational equity is an important piece of education policies. 
All measures might be effectively achieved in the long term if the gender pay gap is narrowed and a greater social cohesion is achieved [21].

\section{Health}

The health pillar includes three factors that measure women's and men's health. The first is the access to health services, which examines the access to any type of health insurance, possession of the national identity card, and the distance to the nearest health center. The second factor is morbidity, which measures hospitalizations and chronic diseases. The third factor is the basic health care services, which cover medical appointments in public health centers and medicine reception. The Pan American Health Organization (PAHO) [22] promotes gender equality in health so that men and women can have good health, avoid incidents, or die from unjust or preventable causes. A person must have a higher purchasing power in order to have good health; hence, this important pillar is correlated with wealth.

This correlation has a large impact on the difference between the situation of men and women. According to Rodriguez [23], in developing countries such as Colombia, socioeconomic status is a critical determinant of the perception of the population's health.

This status varies according to regional income inequality. In Spain, a study with infants and adolescents was conducted to determine the self-perceived health and the quality of life by gender. The results showed that women are twice more likely to perceive worse health and a lower quality of life than men [24].

The United Nations (n.d.) stated that women have less access to health care services due to the lack of resources, even though women demand more health care services throughout their lives (reproductive health). The lack of access to knowledge, nutrition, employment, and income provides fewer opportunities for women to have good health. Empowered women contribute to the health and productivity of their families and communities. Women's reproductive health, the ability to control their own fertility, and the access to information and services to improve their health are essential [4]. Health public policies entail public expenditure, even though the effect of this inequality would lead to more significant results in the households [23].

\section{Autonomy}

The autonomy pillar covers three factors: economic, physical autonomy, and decisionmaking. These three components are important aspects to measure the person's action as an individual and as part of the society. These factors are consistent with ECLAC's [8] autonomy proposal. According to ECLAC [8], physical autonomy refers to women's reproductive rights and gender-related violence; decision-making autonomy refers to the women's involvement in decision-making in politics, and women's participation under conditions of equality; while the economic autonomy is "women's capacity to generate income and personal financial resources, based on access to paid work under conditions of equality with men" (p. 23). This pillar is a major factor for this study because gender equality can't be achieved without the support of social and judicial institutions, access or control of resources, and social or political participation [4].

In regard to the economic autonomy, at the global level, labor markets have inequalities between men and women in regard to opportunities, treatment, and results. In general, women are more likely to stay unemployed and have fewer opportunities to enter the labor force [25].

Economic autonomy explains how women can generate income and resources from paid work under equal conditions with men [17]. In regard to economic empowerment, six out of ten of the world's poorest people are women. Economic inequalities are reflected in women's unpaid work. In general, women continue to be discriminated in the economic sphere [4]. 
Physical autonomy is expressed in two dimensions: women's reproductive rights and gender-based violence [17]. The World Health Organization defines this violence as "the act that results in physical, sexual or psychological harm to women, including threats of such acts or arbitrary deprivation of liberty". On average, one out of every three women around the world has experienced physical and/or sexual violence by the partner [26].

Decision-making autonomy refers to the presence of women in the Government branches and to the measures to promote their full and equal participation [17]. In regard to leadership and political participation, women are underrepresented in managerial positions, elected officials, public administration, etc. This is due to the structural barriers in discriminatory laws and institutions that limit women's opportunity to vote or to be represented; and to the gaps related to education, contacts, resources, and other necessary elements to become leaders [27] (UN, 2012). However, some social movements led by women have resulted in the improvement of well-being indicators for the population's benefit. This demonstrated women's leadership skills and the ability to relate to others [28].

\section{Opportunity}

The opportunity pillar measures the indicators related to the conditions for obtaining the necessary resources to have the direction of the citizens' own lives. This dimension includes access to higher education as the main requirement for better employment opportunities. This component includes the enrollment at art and technology education centers and the number of graduates from universities. It also considers the characteristics of female and masculine employment to measure their participation in the labor market, informality, and underemployment. Finally, it considers women's and men's use of time, taking into account the time spent working during both the workweek and the weekend. The latter is a unique contribution of the GEIR since it is the only index that included this category in its variables.

This pillar is of paramount importance for individual citizens and for society as a whole, since higher education creates knowledge, teaches specific skills, and promotes values; however, there are disparities in the access to higher education. Despite a global increase in supply and the number of enrolled students, some regions have mostly men as higher education graduates and the gap expands in doctorate degrees [20].

As for the use of time, Kanter [29] described women's entrance into the labor market as the most important silent social revolution of the twentieth century. This resulted in profound changes in the labor market, educational attainment, reductions of the female fertility rate, family relations, and greater participation in decision-making [6]. Despite this, there are still great challenges with respect to the equitable participation of women in economic activities.

Women and young people are over-represented in the informal economy and women's incomes are lower in all the employment categories [25]. Globally, women work less time than men in paid work activities and take care of unpaid household work, which involves a significant amount of time [30].

In addition, each factor is broken down into indicators that explain its relevance. The number of indicators per component varies (from two to three) to explain the component more accurately. Tables 2, 3, 4 and 5 show the pillars, factors, indicators and sources of the model, alongside the questions that explain the importance of the components in each dimension.

Each question shows the perspective taken by the index and the elements to be measured. 
Table 2. Factors, Indicators, Variables, Unit and Objectives of the Education Pillar

\begin{tabular}{|c|c|c|c|c|c|}
\hline Factors & Indicator & \multicolumn{2}{|l|}{ Variable } & Unit & Objective \\
\hline \multirow{2}{*}{$\begin{array}{l}\text { Educational } \\
\text { attainment }\end{array}$} & Literacy & \multicolumn{2}{|c|}{$\begin{array}{l}\text { Literacy of men/women }(+15 \\
\text { years old })\end{array}$} & Percentage & \multirow{2}{*}{$\begin{array}{l}\text { Do women and men } \\
\text { have equal access to } \\
\text { primary education? }\end{array}$} \\
\hline & Years of study & $\begin{array}{l}\text { Years of study complete } \\
\text { men/women }(+15 \text { years }\end{array}$ & & Years & \\
\hline \multirow{2}{*}{$\begin{array}{l}\text { Primary } \\
\text { Education }\end{array}$} & $\begin{array}{l}\text { Attendance at } \\
\text { primary school }\end{array}$ & $\begin{array}{l}\text { Attendance at primary } \\
\text { education (boys/girls fro }\end{array}$ & m 6 to & Percentage & \multirow{2}{*}{$\begin{array}{l}\text { Do women and men } \\
\text { have equal access to } \\
\text { secondary education? }\end{array}$} \\
\hline & $\begin{array}{l}\text { Primary school } \\
\text { enrollment }\end{array}$ & $\begin{array}{l}\text { Primary school enrollme } \\
\text { (boys/girls from } 6 \text { to } 11\end{array}$ & yt & Percentage & \\
\hline \multirow{2}{*}{$\begin{array}{l}\text { Secondary } \\
\text { education }\end{array}$} & $\begin{array}{l}\text { Attendance at } \\
\text { secondary school }\end{array}$ & $\begin{array}{l}\text { Attendance at secondary } \\
\text { education (male/female }\end{array}$ & & Percentage & \multirow{2}{*}{$\begin{array}{l}\text { What are men's and } \\
\text { women's } \\
\text { achievements with } \\
\text { regard to the level of }\end{array}$} \\
\hline & $\begin{array}{l}\text { Secondary school } \\
\text { enrollment }\end{array}$ & \multicolumn{2}{|l|}{$\begin{array}{l}\text { Attendance at secondary } \\
\text { education (male/female }\end{array}$} & Percentage & \\
\hline \multicolumn{6}{|c|}{ Table 3. Factors, Indicators, Variables, Unit and Objectives of the Health Pillar } \\
\hline Factors & Indicator & Variable & Unit & & Objective \\
\hline \multirow{3}{*}{$\begin{array}{l}\text { Access to } \\
\text { health }\end{array}$} & $\begin{array}{l}\text { Distance to the } \\
\text { health care center }\end{array}$ & $\begin{array}{l}\text { Men/women do not } \\
\text { receive medical care }\end{array}$ & Perce & age & \multirow{3}{*}{$\begin{array}{l}\text { What are women's and } \\
\text { men's access level to } \\
\text { health services? }\end{array}$} \\
\hline & $\begin{array}{l}\text { National Identity } \\
\text { Card }\end{array}$ & $\begin{array}{l}\text { Men/Women with a } \\
\text { national identity card }\end{array}$ & $\begin{array}{l}\text { Varia } \\
\text { years }\end{array}$ & n $\%$ over the & \\
\hline & Health insurance & $\begin{array}{l}\text { Men/Women with } \\
\text { some type of health }\end{array}$ & Perce & age & \\
\hline \multirow{2}{*}{ Morbidity } & Hospitalizations & $\begin{array}{l}\text { Hospitalized } \\
\text { Men/Women }\end{array}$ & Perce & age & \multirow{2}{*}{$\begin{array}{l}\text { What is the difference } \\
\text { between men's and } \\
\text { women's life } \\
\text { expectancy and health }\end{array}$} \\
\hline & Chronic conditions & $\begin{array}{l}\text { Men/women reported } \\
\text { suffering from a }\end{array}$ & $\begin{array}{l}\text { The } \mathrm{p} \\
\text { relatic }\end{array}$ & $\begin{array}{l}\text { centage in } \\
\text { to the total of }\end{array}$ & \\
\hline \multirow{2}{*}{ Basic care } & $\begin{array}{l}\text { Medical attention at } \\
\text { public health centers }\end{array}$ & $\begin{array}{l}\text { Number of outpatient } \\
\text { medical attention }\end{array}$ & $\begin{array}{l}\text { Numb } \\
1000 \\
\end{array}$ & $\begin{array}{l}\text { r of cases per } \\
\text { bitants. }\end{array}$ & \multirow{2}{*}{$\begin{array}{l}\text { How often do men and } \\
\text { women come to public } \\
\text { health centers? }\end{array}$} \\
\hline & Medicine reception & $\begin{array}{l}\text { Men/Women who } \\
\text { receive medicine }\end{array}$ & Perce & age & \\
\hline
\end{tabular}

Table 4. Factors, Indicators, Variables, Unit and Objectives of the Autonomy Pillar

\begin{tabular}{|c|c|c|c|c|}
\hline Factors & Indicator & Variable & Unit & Objective \\
\hline \multirow{3}{*}{ Economic } & $\begin{array}{l}\text { Economic } \\
\text { dependence }\end{array}$ & $\begin{array}{l}\text { Men/women without own } \\
\text { income }\end{array}$ & $\begin{array}{l}\text { The percentage in } \\
\text { relation to the total of }\end{array}$ & \multirow{3}{*}{$\begin{array}{l}\text { What are the economic } \\
\text { factors that represent } \\
\text { men's and women's } \\
\text { autonomy? }\end{array}$} \\
\hline & Labor income & $\begin{array}{l}\text { Men/women's average } \\
\text { monthly income }\end{array}$ & Current PEN & \\
\hline & Unpaid work & Unpaid family workers & Percentage & \\
\hline \multirow{4}{*}{ Physical } & $\begin{array}{l}\text { Adult sexual } \\
\text { abuse }\end{array}$ & $\begin{array}{l}+18 \text {-year-old men/women rape } \\
\text { victims }\end{array}$ & $\begin{array}{l}\text { Total registered cases } \\
\text { per } 10,000 \text { habitants. }\end{array}$ & \multirow{4}{*}{$\begin{array}{l}\text { Is men's and women's } \\
\text { physical integrity } \\
\text { valued and respected } \\
\text { equally? }\end{array}$} \\
\hline & $\begin{array}{l}\text { Child sexual } \\
\text { abuse }\end{array}$ & $\begin{array}{l}\text { Men/women rape victims } \\
\text { under } 18 \text { years old. }\end{array}$ & $\begin{array}{l}\text { Total registered cases } \\
\text { per } 10,000 \text { habitants. }\end{array}$ & \\
\hline & $\begin{array}{l}\text { Human } \\
\text { trafficking }\end{array}$ & $\begin{array}{l}\text { Men/Women alleged victims } \\
\text { of human trafficking }\end{array}$ & $\begin{array}{l}\text { Total registered cases } \\
\text { per } 10,000 \text { habitants. }\end{array}$ & \\
\hline & $\begin{array}{l}\text { Family } \\
\text { violence }\end{array}$ & $\begin{array}{l}\text { Registered cases of family } \\
\text { and/or sexual violence }\end{array}$ & $\begin{array}{l}\text { Total registered cases } \\
\text { per } 10,000 \text { habitants. }\end{array}$ & \\
\hline \multirow{3}{*}{$\begin{array}{l}\text { Decision- } \\
\text { making }\end{array}$} & Councilors & $\begin{array}{l}\text { Number of } \\
\text { councilmen/councilwomen }\end{array}$ & $\begin{array}{l}\text { Total cases per } \\
10,000 \text { habitants. }\end{array}$ & \multirow{3}{*}{$\begin{array}{l}\text { How do men and } \\
\text { women participate in } \\
\text { democracy and politics } \\
\text { in their regions? }\end{array}$} \\
\hline & $\begin{array}{l}\text { Municipal } \\
\text { governments }\end{array}$ & $\begin{array}{l}\text { Number of men/women } \\
\text { mayors. }\end{array}$ & $\begin{array}{l}\text { Total cases per } \\
10,000 \text { habitants. }\end{array}$ & \\
\hline & Parliament & $\begin{array}{l}\text { Number of men/women } \\
\text { parliamentarians }\end{array}$ & $\begin{array}{l}\text { Total cases per } \\
10,000 \text { habitants. }\end{array}$ & \\
\hline
\end{tabular}


Table 5. Factors, Indicators, Variables, Unit and Objectives of the Opportunities Pillar

\begin{tabular}{|c|c|c|c|c|}
\hline Factors & Indicator & Variable & Unit & Objective \\
\hline \multirow{3}{*}{$\begin{array}{l}\text { Access to } \\
\text { higher } \\
\text { education }\end{array}$} & University enrollment & $\begin{array}{l}\text { Men/women between } 17 \\
\text { and } 24 \text { years old enrolled }\end{array}$ & Percentage & \multirow{3}{*}{$\begin{array}{l}\text { What is the } \\
\text { highest level of } \\
\text { education } \\
\text { achieved by } \\
\text { women and men? }\end{array}$} \\
\hline & $\begin{array}{l}\text { Enrollment in art } \\
\text { higher education }\end{array}$ & $\begin{array}{l}\text { Men/Women at artistic } \\
\text { training centers }\end{array}$ & $\begin{array}{l}\text { Total enrollments } \\
\text { per } 10,000\end{array}$ & \\
\hline & $\begin{array}{l}\text { Enrollment in } \\
\text { technological higher }\end{array}$ & $\begin{array}{l}\text { Men/Women at } \\
\text { technological training }\end{array}$ & $\begin{array}{l}\text { Total enrollments } \\
\text { per } 10,000\end{array}$ & \\
\hline \multirow{3}{*}{ Employment } & Informality & Male/female informality & Percentage & \multirow{3}{*}{$\begin{array}{l}\text { Are there equal } \\
\text { opportunities to } \\
\text { enter the labor } \\
\text { market for women } \\
\text { and men? }\end{array}$} \\
\hline & $\begin{array}{l}\text { Participation in the } \\
\text { labor market. }\end{array}$ & $\begin{array}{l}\text { Economically active } \\
\text { men/women in an }\end{array}$ & Percentage & \\
\hline & Underemployment & $\begin{array}{l}\text { Economically active } \\
\text { underemployed }\end{array}$ & Percentage & \\
\hline \multirow{3}{*}{ Use of time } & $\begin{array}{l}\text { Time used in paid } \\
\text { labor }\end{array}$ & $\begin{array}{l}\text { Average hours per week } \\
\text { men/women spent doing }\end{array}$ & Hours per week & \multirow{3}{*}{$\begin{array}{l}\text { How do men and } \\
\text { women distribute } \\
\text { their time? }\end{array}$} \\
\hline & Employer & $\begin{array}{l}\text { Men/women who employ } \\
\text { others in a registered }\end{array}$ & Percentage & \\
\hline & Weekend labor & $\begin{array}{l}\text { Total hours of labor } \\
\text { during the weekend by }\end{array}$ & $\begin{array}{l}\text { Hours per } \\
\text { weekend }\end{array}$ & \\
\hline
\end{tabular}

\section{GEIR Background}

The ongoing cultural processes in Peru called for the GEIR. The extreme centralization during most of Peruvian history led to the regions' underdevelopment. In recent years, several attempts to reform the political, tax and administrative centralization were made. Despite the mixed results of these policies, the transfer of resources to subnational governments increased as a result of the sustained economic growth, but it is still the backbone of decentralization and regional budgets regardless of the recent deceleration of economic growth. Therefore, a major factor in the future development of the country is the subnational governments' ability to optimize public spending according to cultural and tax constrains (IPS, 2017). In addition, in the last decade, there is a marked and increasing societal interest in gender issues. In 2007, the member states of the ECLAC requested the constitution of a gender equality observatory during a Regional Conference held in Quito [31]. Then, the creation of the SDGs (UN) in 2015 included gender equality as the goal number 5. In Peru, the creation of the "Ni una menos [Not one woman less]" movement in 2016 was a direct response to gender violence and quickly gained support in the capital and most regions (La Republica, 2018). The government took several actions to address "Ni una menos" and deal with the gender gap in general.

As these decentralization and gender gap awareness processes develop, the need for a better progress indicator and a better summary of interesting variables for policymakers becomes more evident. Thus, we created the GEIR as a tool to evaluate the needs of each region and to assist the local authorities to make strategic spending according to those needs.

This would represent a significant improvement in contrast to the current indicators used by the Peruvian government, which mostly reward the execution of the scheduled budget regardless of the result. Instead, the GEIR helps measuring the ability of subnational governments to translate the economic growth into social progress [13] taking into account that the effects of this progress might not be homogenous for women and men. Hence, this index presents different results for each and emphasizes the difference between the scores of men and women at the national and regional level. 


\section{Results}

Accuracy depends on the quality of the data used to create any index. The GEIR has statistical information collected from secondary sources and it also includes primary information collected from specific surveys conducted in all the regions of the country. The secondary sources are official statistics published mostly by the National Institute of Statistics and Data Processing (INEI), with specific data from the Ministry of Education (MINEDU), the Ministry of Health (MINSA), the Office of The Attorney General and the National Vital Statistics and Civil Registry Office (RENIEC), the entity responsible of the registry of identified population. The indicators - health, education, autonomy, and opportunities - were selected based on these sources of information. In addition, the government has taken measures to ensure the transparency and usefulness of the data for policy-making and scientific research by aligning the INEI's standards to those of the United Nations and EUROSTAT [32].

With the required information to create the index, the next step is standardizing the data, and verifying its suitability. Table 6 shows the results of Cronbach's Alpha and KMO for each factor of the GEIR with both tests above their recommended thresholds in all cases.

Thus, validating the internal consistency of the variables within each factor and the goodness of fit.

Table 6. Statistical Analysis by Dimension

\begin{tabular}{|c|c|c|c|}
\hline Pilar & Factor & Cronbach'Alpha & KMO \\
\hline \multirow{3}{*}{ Education } & Primary education & 0,9667 & 0,5000 \\
\hline & Secondary education & 0,9737 & 0,5000 \\
\hline & Educational attainment & 0,8176 & 0,5000 \\
\hline \multirow{3}{*}{ Health } & Access to health & 0,8247 & 0,6916 \\
\hline & Morbidity & 0,7164 & 0,5000 \\
\hline & Basic care & 0,8357 & 0,5000 \\
\hline \multirow{3}{*}{ Autonomy } & Economic & 0,8505 & 0,6395 \\
\hline & Physical & 0,9944 & 0,7911 \\
\hline & Decision-making & 0,8485 & 0,5591 \\
\hline \multirow{3}{*}{ Opportunity } & Access to higher education & 0,8124 & 0,7134 \\
\hline & Employment & 0,9453 & 0,7597 \\
\hline & Use of time & 0,8211 & 0,6548 \\
\hline
\end{tabular}

The following step is the principal component analysis (PCA) (Appendix A) and setting the utopias and dystopias for every indicator. The use of the Min-Max method allows to assign each pillar a value from 0 to 100 depending on the level of achievement. In order to show the progress of each gender in every region of Peru, and facilitate the comparison, a 7point scale was used. It ranges from: extremely low ( 25 to 34 points), very low (35 to 44 points), low (45 to 54 points), medium-low (55 to 64 points), medium-high (65 to 74 points), high ( 75 to 84 points), and very high ( 85 to 100 points).

Table 7 shows the results for men and women, together with the existing gender gap by region, the results by dimension of the women index, the men index and the gender gap can be reviewed in Appendixes B to D. In 2018 none of the regions were able to score higher than medium-low, a worrying situation for the country, and the gender gap was significant. Despite the troubling breach, not all pillars have a large gap, and the situation can vary a lot among the regions. Health and education show a more equal situation, even though differences still 
exist. In the latter, there is even a reversal in 4 regions, with women's score being superior to the men. As for regional inequality, the highest scores were obtained in the coastal regions of the country, particularly the capital and southern coast, a historically better developed area.

Meanwhile, most regions in the Andes and the Amazon have very low development for men and women, and the gender gap is also large, with a notable exception in Ucayali.

However, it should be noted that having relatively high development does not mean less gender inequality, Moquegua has one of the largest breaches in gender equality while also having very high scores for men's index and women's index, being first and fourth respectively. An inverse situation can be observed for Loreto, ranking $25^{\text {th }}$ and $18^{\text {th }}$ while having the third smallest breach. Another result of interest is the size of the gap by dimension, with the opportunity pillar and autonomy pillar having the worst breaches. The latter has by far the largest gender gap, with an average national difference of -26.8 as shown in the Appendix D. It is no coincidence that factors within this pillar, such as gender violence and economic dependence, are the issues brought up by "Ni una menos" movement.

Table 7. General results of the GEIR - 2019

\begin{tabular}{llllll}
\hline Region & Women Index & Ranking & Men Index & Ranking & Gender gap \\
\hline Piura & 37.0 & 13 & 44.8 & 19 & -7.9 \\
Ucayali & 39.5 & 10 & 47.6 & 16 & -8.0 \\
Loreto & 32.7 & 18 & 41.3 & 25 & -8.6 \\
Lima (city) & 47.9 & 2 & 56.7 & 4 & -8.7 \\
Ica & 48.5 & 1 & 57.7 & 3 & -9.2 \\
Tumbes & 42.5 & 6 & 52.6 & 8 & -10.1 \\
PERÚ & 37.9 & 12 & 48.4 & 14 & -10.5 \\
Lambayeque & 39.1 & 11 & 49.6 & 12 & -10.5 \\
La Libertad & 36.5 & 14 & 47.9 & 15 & -11.4 \\
Lima (provinces) & 40.2 & 9 & 51.8 & 11 & -11.6 \\
San Martín & 29.7 & 21 & 41.4 & 24 & -11.7 \\
Huánuco & 28.4 & 23 & 40.7 & 26 & -12.3 \\
Callao & 42.6 & 5 & 55.2 & 5 & -12.7 \\
Junín & 35.3 & 16 & 48.6 & 13 & -13.3 \\
Amazonas & 30.6 & 20 & 44.3 & 21 & -13.7 \\
Cajamarca & 25.1 & 27 & 39.0 & 27 & -14.0 \\
Madre de Dios & 40.7 & 7 & 55.0 & 6 & -14.3 \\
Tacna & 40.3 & 8 & 54.7 & 7 & -14.4 \\
Puno & 32.7 & 19 & 47.3 & 18 & -14.6 \\
Ayacucho & 27.3 & 24 & 42.6 & 23 & -15.2 \\
Arequipa & 43.8 & 3 & 59.2 & 2 & -15.4 \\
Cusco & 28.9 & 22 & 44.4 & 20 & -15.5 \\
Áncash & 36.3 & 15 & 52.0 & 10 & -15.6 \\
Moquegua & 42.7 & 4 & 59.9 & 1 & -17.1 \\
Pasco & 35.0 & 17 & 52.4 & 9 & -17.3 \\
Huancavelica & 26.1 & 25 & 43.7 & 22 & -17.6 \\
Apurímac & 25.7 & 26 & 47.3 & 17 & -21.6 \\
\hline & 25 & 23 & & \\
\hline
\end{tabular}

*Due to the large cultural, economic and demographic difference between the city of Lima and its surrounding areas, this region 


\section{Discussion}

This paper introduces a novel gender equality index that is useful for public policy decisions and shows the results of its application in Peru. The main contributions of this index are the recognition of the relevance of the time use, an important variable to measure unpaid labor - which is a major gender issue, as well as the identification of the regional information and the existing gender gap in a country. This index overcame one of the main criticisms of early indicators, which is the inability to separate gender equality from local development. By capturing regional differences, it becomes easier to understand the current situation of a country through the national score. The information that otherwise would be unavailable becomes visible. This, alongside the decision to split the scores for men and women, makes the index a useful tool to identify gender gaps, independently from the level of development in an area. Therefore, it gives policymakers a powerful tool for the strategic allocation of resources to the regions.

However, it is worth to note that the availability and quality of secondary data in Latin American regions is an important constraint for developing indices. This is a major issue for applying the GEIR in other countries, since the index requires different data of every region.

Only the Government can collect this kind of information, which means that it is necessary to have cooperation agreements between the academic organizations that create the index and the Government. This might even allow including specific questions in the yearly surveys made by most governments, which could give valuable information for new GEIRs.

The GEIR should not be taken as a complete and final index, but instead as a part of the development process of necessary tools to identify inequalities. Further publications of the GEIR in Peru or in other countries would help to identify limitations or potential additions to refine the index and increase its usefulness as a policy-making tool.

\section{REFERENCES}

[1] United Nations [UN]. (2016). 2030 Agenda and the sustainable development goals. Retrieved from Http://www.sela.org/mean/2262361/agenda-2030-and-the-objectives-of-development-sustainable development.pdf unf

[2] United Nations Educational, Scientific and Cultural Organization [UNESCO]. (2017a). Gender equality France: Author. Retrieved from http://www.unesco.org/new/es/havana/areas-of-action/igualdad-degenero/

[3] World Economic Forum. (2018). The Global Gender Gap Report 2018. Retrieved from http://www

[4] United Nations Population Fund [UNFPA]. (2014). Igualdad entre los géneros. Retrieved from http://www.unfpa.org/es/igualdad-entre-los-g\%C3\%A9neros

[5] United Nations [UN]. (1995). Fourth World Conference on Women Beijing Declaration. Retrieved from http://www.un.org/womenwatch/daw/beijing/platform/declar.htm

[6] Economic Commission for Latin America and the Caribbean [ECLAC]. (2004). Caminos hacia la equidad de género en América Latina y el Caribe. Chile: Author.

[7] United Nations [UN]. (2015). Objetivos de Desarrollo del Milenio Peru: The United Nations System of Peru. Retrieved from http://onu.org.pe/que-son-los-odm/

[8] Economic Commission for Latin America and the Caribbean [ECLAC]. (2010). Manual de uso del observatorio de igualdad de género de América Latina y el Caribe. Mexico, D.F.: Author.

[9] Castro, C., \& Álvarez, B. (2011). La igualdad en la Responsabilidad Social de las Empresas. Retrieved from http://www.castello.es/web20/archivos/contenidos/61/D021_Igualdad_RSE.pdf

[10] Porter, M \& Scott, A, (2018a). Social Progress Index 2018 Washington, DC: Social Progress Imperative.

[11] Dávila, M. (2004). Indicadores de género: guía práctica. Junta de Andalucía: Andalusian Women's Institute. Consejería de igualdad y políticas sociales. Retrieved from http://www.juntadeandalucia.es/iamindex.php/recursos-y-servicios/2013-04-19-11-45-20/funcstartdown/616/ 
[12] United Nations Development Programme [UNDP]. (2010). Informe sobre Desarrollo Humano 2010. Retrieved from: http://hdr.undp.org/sites/default/files/hdr_2010_es_complete_reprint.pdf

[13] CENTRUM Católica (2017). Índice de Progreso Social Regional del Perú 2017. Lima, Peru: CENTRUM Publishing.

[14] Organization for Economic Co-operation and Development [OECD] \& Joint Research Center [JRC]. (2008). Handbook on constructing composite indicators: methodology and user guide. Paris: OECD.

[15] Benzaquen, J., Del Carpio, L., Zegarra, L., \& Valdivia, C. (2010). Un índice regional de competitividad para un país. Santiago: ECLAC. Retrieved from http://repositorio.cepal.org/bitstream/handle/11362/11417/102069086_es.pdf

[16] Bobadilla, P., Del Aguila, L. \& M. de la L. Morgan (1998). Diseño y evaluación de proyectos de desarrollo, Lima, Pact-usaid.

[17] Economic Commission for Latin America and the Caribbean [ECLAC]. (2016). Incorporar la perspectiva de género en la producción estadística supone interrorar sobre como impactan de forma diferenciar determinados fenómenos a hombres y mujeres. Chile: Author. Retrieved from http://www.cepal.org/es/notas/incorporar-la-perspectiva-genero-la-produccion-estadistica-suponeinterrogar-como-impactan

[18] Milosavljevic, V. (2007). Estadísticas para la equidad de género. Magnitudes y tendencias en América Latina. Chile: UNESCO.

[19] Porter, M \& Scott, A, (2018b). 2018 Social Progress Index: Methodology Summary. Washington, DC: Social Progress Imperative. Retrieved from:

[20] United Nations Educational, Scientific and Cultural Organization [UNESCO]. (2017b). Seis maneras de asegurar que la educación superior no deje a nadie atrás. Paris: Author. Retrieved from: http://unesdoc.unesco.org/images/0024/002478/247862S.pdf

[21] Giménez, G., \& Castro, G. (2015). ¿Por qué los estudiantes de colegios públicos y privados de Costa Rica obtienen distintos resultados académicos? Journal Citation Reports, pp. 195-223.

[22] Pan American Health Organization [PAHO] (24 May 2009). Equidad de género en salud. Programa mujer, salud y desarrollo. http://www1.paho.org/Spanish/AD/GE/GenderEquityinHealthsp.pdf

[23] Rodríguez, S. (2016). La desigualdad de ingresos y salud en Colombia. Perfiles Latinoamericanos, pp. 265-296.

[24] Vélez, R., López, S., \& Rajmil, L. (2009). Género y salud percibida en la infancia y la adolescencia en España. Gaceta Sanitaria, 23(5), pp. 433-439.

[25] International Labour Organization [ILO]. (2013). La economía informal y el trabajo decente: Una guía de recursos sobre políticas apoyando a transición hacia la formalidad. Geneva: Author. Retrieved from http://www.ilo.org/wcmsp5/groups/public/@ed_emp/@emp_policy/documents/publication/wcms_2294 29.pdf

[26] World Health Organization. [WHO]. (2016). Violence against women. Geneva: Author. Retrieved from: http://www.who.int/mediacentre/factsheets/fs239/es/

[27] United Nations [UN] (2012). Leadership and political participation. New York, NY: UN Women. Retrieved from http://www.unwomen.org/es/what-we-do/leadership-and-political-participation.

[28] Tabbush, C., \& Caminotti, M. (2015). Igualdad de Género y movimientos sociales en la Argentina posneoliberal: La organización Barrial Tupac Amaru. Journal Citation Reports, pp. 147-171.

[29] Kanter, R. (1977). Men and women in corporations. New York NY: Basic Books.

[30] International Labour Organization [ILO]. (2016). Women in the workplace. Geneva: Author. Retrieved from Http://www.ilo.org/wcmsp5/groups/public/---dgreports/---dcomm/--publ/documents/publication/wcms_483214.pdf

[31] Economic Commission for Latin America and the Caribbean [ECLAC]. (2019). About the Observatory. Retrieved from Gender Equality Observatory: https://oig.cepal.org/en/about-observatory

[32] National Institute of Statistics and Data Processing [INEI]. (2012). Código de buenas prácticas estadísticas. Retrieved from https://www.inei.gob.pe/media/buenaspracticas/Codigo_Buenas_Practicas.pdf

\section{Article history:}

Received 23 February 2020

Accepted 18 May 2020 
Appendix A

Weights used - Women's Index by Dimension 2018

\begin{tabular}{|c|c|c|c|}
\hline Pillar & Factor & Indicator & Weight \\
\hline \multirow{6}{*}{ Education } & \multirow{2}{*}{ Educational attainment } & Literacy & 0.50 \\
\hline & & Years of study & 0.50 \\
\hline & \multirow{2}{*}{ Primary education } & Attendance at primary school & 0.50 \\
\hline & & Primary school enrollment & 0.50 \\
\hline & \multirow{2}{*}{ Secondary education } & Attendance at secondary school & 0.50 \\
\hline & & Secondary school enrollment & 0.50 \\
\hline \multirow{7}{*}{ Health } & \multirow{3}{*}{ Access to health } & Distance to the health care center & 0.34 \\
\hline & & National Identity Card & 0.34 \\
\hline & & Health insurance & 0.31 \\
\hline & \multirow{2}{*}{ Morbidity } & Hospitalizations & 0.50 \\
\hline & & Chronic conditions & 0.50 \\
\hline & \multirow{2}{*}{ Basic care } & $\begin{array}{l}\text { Medical attention at public health } \\
\text { centers }\end{array}$ & 0.50 \\
\hline & & Medicine reception & 0.50 \\
\hline \multirow{10}{*}{ Autonomy } & \multirow{3}{*}{ Economic } & Economic dependence & 0.35 \\
\hline & & Labor income & 0.36 \\
\hline & & Unpaid work & 0.30 \\
\hline & \multirow{4}{*}{ Physical } & Adult sexual abuse & 0.25 \\
\hline & & Child sexual abuse & 0.25 \\
\hline & & Human trafficking & 0.25 \\
\hline & & Family violence & 0.25 \\
\hline & \multirow{3}{*}{ Decision-making } & Councilors & 0.37 \\
\hline & & Municipal governments & 0.26 \\
\hline & & Parliament & 0.37 \\
\hline \multirow{9}{*}{ Opportunity } & \multirow{3}{*}{$\begin{array}{l}\text { Access to higher } \\
\text { education }\end{array}$} & University enrollment & 0.34 \\
\hline & & Enrollment in art higher education & 0.34 \\
\hline & & $\begin{array}{l}\text { Enrollment in technological higher } \\
\text { education }\end{array}$ & 0.33 \\
\hline & \multirow{3}{*}{ Employment } & Informality & 0.33 \\
\hline & & Participation in the labor market. & 0.33 \\
\hline & & Underemployment & 0.34 \\
\hline & \multirow{3}{*}{ Use of time } & Time used in paid labor & 0.36 \\
\hline & & Employer & 0.30 \\
\hline & & Weekend labor & 0.34 \\
\hline
\end{tabular}




\section{Appendix B}

Results of the Women's Index by Dimension 2018

\begin{tabular}{|c|c|c|c|c|c|}
\hline Region & General & Education & Health & Autonomy & Opportunity \\
\hline Ica & 48.5 & 50.2 & 49.8 & 32.2 & 61.9 \\
\hline Lima (city) & 47.9 & 56.3 & 39.8 & 41.9 & 53.7 \\
\hline Arequipa & 43.8 & 53.9 & 37.9 & 31.0 & 52.6 \\
\hline Moquegua & 42.7 & 50.1 & 38.9 & 34.2 & 47.7 \\
\hline Callao & 42.6 & 46.9 & 43.7 & 42.2 & 37.5 \\
\hline Tumbes & 42.5 & 47.1 & 39.7 & 36.2 & 47.0 \\
\hline Madre de Dios & 40.7 & 43.0 & 45.6 & 29.9 & 44.1 \\
\hline Tacna & 40.3 & 55.7 & 35.1 & 28.5 & 41.7 \\
\hline Lima (provinces) & 40.2 & 48.3 & 48.8 & 31.7 & 31.9 \\
\hline Ucayali & 39.5 & 38.9 & 45.7 & 36.3 & 37.1 \\
\hline Lambayeque & 39.1 & 37.9 & 47.2 & 41.0 & 30.1 \\
\hline PERÚ & 37.9 & 40.2 & 39.7 & 34.4 & 37.4 \\
\hline Piura & 37.0 & 37.4 & 44.2 & 39.6 & 26.7 \\
\hline La Libertad & 36.5 & 37.2 & 38.2 & 39.7 & 30.9 \\
\hline Áncash & 36.3 & 38.8 & 39.0 & 38.0 & 29.5 \\
\hline Junín & 35.3 & 38.6 & 40.1 & 29.3 & 33.1 \\
\hline Pasco & 35.0 & 39.1 & 39.0 & 30.9 & 31.2 \\
\hline Loreto & 32.7 & 21.5 & 39.4 & 36.6 & 33.3 \\
\hline Puno & 32.7 & 39.3 & 30.3 & 34.8 & 26.3 \\
\hline Amazonas & 30.6 & 27.0 & 36.5 & 35.7 & 23.2 \\
\hline San Martín & 29.7 & 20.8 & 40.0 & 34.8 & 23.2 \\
\hline Cusco & 28.9 & 24.3 & 28.0 & 28.7 & 34.7 \\
\hline Huánuco & 28.4 & 17.5 & 42.5 & 29.7 & 23.9 \\
\hline Ayacucho & 27.3 & 14.3 & 37.8 & 30.2 & 27.0 \\
\hline Huancavelica & 26.1 & 15.4 & 40.3 & 31.5 & 17.0 \\
\hline Apurímac & 25.7 & 19.3 & 30.6 & 29.7 & 23.2 \\
\hline Cajamarca & 25.1 & 13.4 & 37.8 & 32.2 & 16.8 \\
\hline
\end{tabular}


Appendix C

Results of the Men's Index by Dimension 2018

\begin{tabular}{|c|c|c|c|c|c|}
\hline Region & General & Education & Health & Autonomy & Opportunity \\
\hline Moquegua & 59.9 & 51.4 & 45.7 & 76.4 & 66.1 \\
\hline Arequipa & 59.2 & 57.9 & 40.6 & 66.4 & 71.9 \\
\hline Ica & 57.7 & 45.9 & 52.1 & 64.5 & 68.3 \\
\hline Lima (city) & 56.7 & 52.4 & 42.3 & 64.2 & 67.7 \\
\hline Callao & 55.2 & 55.3 & 46.1 & 62.8 & 56.7 \\
\hline Madre de Dios & 55.0 & 53.0 & 50.1 & 68.4 & 48.5 \\
\hline Tacna & 54.7 & 58.6 & 38.4 & 66.6 & 55.0 \\
\hline Tumbes & 52.6 & 53.5 & 42.6 & 62.4 & 51.9 \\
\hline Pasco & 52.4 & 47.3 & 44.5 & 67.9 & 49.9 \\
\hline Áncash & 52.0 & 52.6 & 44.4 & 66.6 & 44.3 \\
\hline Lima (provinces) & 51.8 & 45.4 & 50.0 & 67.1 & 44.8 \\
\hline Lambayeque & 49.6 & 38.6 & 47.5 & 61.1 & 51.2 \\
\hline Junín & 48.6 & 40.6 & 44.1 & 63.9 & 45.9 \\
\hline PERÚ & 48.4 & 41.3 & 42.4 & 61.2 & 48.8 \\
\hline La Libertad & 47.9 & 41.5 & 41.2 & 62.0 & 46.9 \\
\hline Ucayali & 47.6 & 31.7 & 48.1 & 59.6 & 50.8 \\
\hline Apurímac & 47.3 & 44.1 & 35.3 & 71.8 & 38.1 \\
\hline Puno & 47.3 & 55.0 & 34.2 & 62.5 & 37.3 \\
\hline Piura & 44.8 & 35.6 & 45.3 & 59.2 & 39.1 \\
\hline Cusco & 44.4 & 36.3 & 31.6 & 59.5 & 50.5 \\
\hline Amazonas & 44.3 & 36.7 & 36.8 & 69.7 & 34.0 \\
\hline Huancavelica & 43.7 & 30.7 & 42.4 & 74.1 & 27.6 \\
\hline Ayacucho & 42.6 & 28.9 & 42.0 & 68.3 & 31.0 \\
\hline San Martín & 41.4 & 27.9 & 41.6 & 62.8 & 33.3 \\
\hline Loreto & 41.3 & 27.3 & 40.2 & 57.6 & 40.1 \\
\hline Huánuco & 40.7 & 26.1 & 45.7 & 62.9 & 28.1 \\
\hline Cajamarca & 39.0 & 26.5 & 41.0 & 60.4 & 28.2 \\
\hline
\end{tabular}




\section{Appendix D}

Gender Gap - Women's Index by Dimension 2018

\begin{tabular}{|c|c|c|c|c|c|}
\hline Region & General & Education & Health & Autonomy & Opportunity \\
\hline Piura & -7.9 & 1.8 & -1.1 & -19.6 & -12.4 \\
\hline Ucayali & -8.0 & 7.2 & -2.4 & -23.3 & -13.7 \\
\hline Loreto & -8.6 & -5.8 & -0.8 & -21.0 & -6.8 \\
\hline Lima (city) & -8.7 & 3.9 & -2.5 & -22.4 & -14.0 \\
\hline Ica & -9.2 & 4.3 & -2.3 & -32.3 & -6.5 \\
\hline Tumbes & -10.1 & -6.4 & -2.9 & -26.2 & -4.9 \\
\hline PERÚ & -10.5 & -1.1 & -2.7 & -26.8 & -11.4 \\
\hline Lambayeque & -10.5 & -0.7 & -0.2 & -20.1 & -21.1 \\
\hline La Libertad & -11.4 & -4.3 & -3.1 & -22.3 & -16.0 \\
\hline Lima (provinces) & -11.6 & 2.8 & -1.2 & -35.3 & -12.8 \\
\hline San Martín & -11.7 & -7.1 & -1.5 & -28.0 & -10.2 \\
\hline Huánuco & -12.3 & -8.6 & -3.3 & -33.2 & -4.2 \\
\hline Callao & -12.7 & -8.4 & -2.3 & -20.6 & -19.2 \\
\hline Junín & -13.3 & -1.9 & -4.0 & -34.6 & -12.8 \\
\hline Amazonas & -13.7 & -9.6 & -0.4 & -34.0 & -10.8 \\
\hline Cajamarca & -14.0 & -13.0 & -3.2 & -28.2 & -11.4 \\
\hline Madre de Dios & -14.3 & -9.9 & -4.5 & -38.5 & -4.4 \\
\hline Tacna & -14.4 & -2.9 & -3.3 & -38.0 & -13.3 \\
\hline Puno & -14.6 & -15.7 & -3.9 & -27.7 & -10.9 \\
\hline Ayacucho & -15.2 & -14.6 & -4.2 & -38.1 & -4.0 \\
\hline Arequipa & -15.4 & -4.0 & -2.7 & -35.4 & -19.3 \\
\hline Cusco & -15.5 & -12.0 & -3.6 & -30.7 & -15.8 \\
\hline Áncash & -15.6 & -13.7 & -5.4 & -28.5 & -14.8 \\
\hline Moquegua & -17.1 & -1.3 & -6.7 & -42.2 & -18.4 \\
\hline Pasco & -17.3 & -8.2 & -5.5 & -37.0 & -18.7 \\
\hline Huancavelica & -17.6 & -15.3 & -2.1 & -42.5 & -10.6 \\
\hline Apurímac & -21.6 & -24.8 & -4.7 & -42.2 & -14.8 \\
\hline
\end{tabular}

